\title{
KONSTRUKSI MAKNA KENCAN DI SITUS PENCARIAN JODOH TINDER (Studi Fenomenologi Pada Pria Pengguna Tinder Di Jakarta)
}

\author{
Merry Fridha \\ Meria Octavianti \\ Program Studi Ilmu Komunikasi, FISIP, Universitas Islam Balitar \\ Fakultas Ilmu Komunikasi, Universitas Padjadjaran \\ Email : merry.imeng@gmail.com ;meria.octavianti@unpad.ac.id
}

\begin{abstract}
The use of a mate search application is currently being used by the people of Indonesia crowded. This is evidenced by the number of applications such as beetalk mate search, meowchat, OkCupid, tinder and much more. Mate search site can be trusted to provide solutions for speed and accuracy of the arrival of a mate for its users. This phenomenon will create a shift in meaning where in the past dating dating will be conducted by a couple who have gone through the introductory stage, approach, new assessment followed by a date. But today the stage is shortened to introduction through tinder mate search application, and then meet for a date. So dating conducted a blind date (blind date) because the two people familiar with the dating without opponents date. This attracted the attention of researchers so that researchers intrigued to know how meaning construction dating site matchmaking search Tinder (Phenomenology Study on Men Tinder Users in Jakarta). The theory used in this research is the theory of Computer Mediated Communication (CMC) and the Social Penetration Theory. With Qualitative research methodologies and approaches phenomenology, the study provides an overview of Constructivist paradigm will shift the meaning of dating for men dating search app users in the application tinder. The results showed that male informants in Jakarta tinder users will choose a date, like selecting items preferably in the online shop. If they like the woman then they will be invited to meet and relationships can be moved quickly towards the dating stage. Meaning of dating that is identified with the stages of relationship "intimate" into shorter stages.
\end{abstract}

Keywords: Construction Meaning, dating, online dating app Tinder, Computer mediated communication

\begin{abstract}
ABSTRAK
Penggunaan aplikasi pencarian jodoh saat ini sedang ramai digunakan oleh masyarakat Indonesia. Hal ini dibuktikan dengan banyaknya aplikasi pencarian jodoh seperti beetalk, meowchat, okcupid, tinder dan masih banyak lagi yang lainnya. Situs pencarian jodoh dipercaya dapat memberi solusi akan kecepatan dan ketepatan datangnya jodoh bagi penggunanya. Fenomena ini membuat pergeseran makna akan kencan dimana pada masa lalu kencan akan dilakukan oleh pasangan yang telah melalui tahap perkenalan, pendekatan, penjajakan baru dilanjutkan dengan kencan. Namun dewasa ini tahapan tersebut dipersingkat menjadi perkenalan melalui aplikasi pencarian jodoh tinder, lalu bertemu untuk kencan. Sehingga kencan yang dilakukan merupakan kencan buta (blind date) sebab kedua orang berkencan tanpa mengenal dengan baik lawan kencannya. Hal ini menarik perhatian peneliti sehingga peneliti tergelitik untuk mengetahui bagaimana konstruksi makna kencan di situs pencarian jodoh Tinder (Studi Fenomenologi pada Pria Pengguna Tinder di Jakarta). Teori
\end{abstract}


yang digunakan dalam penelitian ini adalah teori Computer Mediated Communication (CMC) dan Teori Penetrasi Sosial. Dengan metodologi penelitian Kualitatif dan Pendekatan Fenomenologi, penelitian berparadigma Konstruktivis ini memberikan gambaran akan adanya pergeseran makna kencan bagi laki-laki pengguna aplikasi pencarian jodoh di aplikasi tinder. Hasil penelitian menunjukkan bahwa nara sumber laki-laki pengguna tinder di Jakarta akan memilih teman kencan, seperti layaknya memilih barang yang disukai di online shop. Bila mereka menyukai perempuan tersebut maka mereka akan mengajak bertemu dan hubungan dapat bergerak cepat menuju tahap kencan. Makna kencan yang diidentikkan dengan tahapan hubungan "intim" menjadi lebih singkat tahapannya.

Kata kunci: Konstruksi Makna, Kencan, Tinder Aplikasi kencan online, Computer mediated communication.

\section{PENDAHULUAN}

Kebudayaan manusia telah banyak berubah oleh faktor penemuan dan perkembangan teknologi komunikasi. Masuk ke dunia komunikasi dan informasi tak ubahnya seperti perpindahan masyarakat dari masyarakat petani ke industri, di mana seluruh dimensi vital manusia terpengaruh. Mulai dari kehidupan sosial, ekonomi maupun yang lainnya. Dunia di milenium ketiga berada di bawah pengaruh komputer sehingga memiliki wajah baru. Sebuah masyarakat jaringan yang telah memasuki ranah kehidupan manusia. Revolusi informasi dan komunikasi menyebabkan perubahan besar pada pola kehidupan manusia.

$$
\text { Pola kehidupan masyarakat }
$$
Indonesia dewasa ini memperlihatkan ketergantungan yang tinggi pada teknologi informasi. Ini dapat dilihat dari kebiasaan masyarakat Indonesia saat ini yang menghabiskan rata-rata waktunya sekitar
117 menit di depan komputer, 181 menit di depan smartphone, dan 110 menit di depan tablet. Ini adalah rata-rata, artinya lebih banyak lagi masyarakat yang menghabiskan waktu di depan layar lebih dari ini. Untuk pekerja kantoran rata-rata bisa menghabiskan hampir seharian kerja di depan komputer (dengan rata-rata total jam kerja 8 jam per hari). Tentu hal ini memperlihatkan gejala ketergantungan manusia modern terhadap perangkat modern bernama komputer. Pakar chiropractic Rishi Loatey menemukan bahwa 82 persen masyarakat urban menghabiskan enam jam di depan komputer. Dan tentu saja angka pengguna komputer akan semakin bertambah demikian juga yang terjadi di Indonesia (Daryanto, 2007:9). Ketergantungan terhahadap teknologi informasi ini meresap dalam kehidupan sehari-hari. Banyak dampak positif dari perkembangan teknologi informasi seperti contohnya adalah semakin memudahkan seseorang 
Merry Fridha, Meria Octavianti, Konstruksi Makna Kencan Di Situs Pencarian Jodoh Tinder (Studi Fenomenologi Pada Pria Pengguna Tinder Di Jakarta)

untuk melakukan kegiatan sehari-hari terutama dalam hal berkomunikasi. Penggunaan sosial media semakin masif dalam menggunakan waktu luang mereka dengan bermedia.

Berbagai aplikasi yang tersedia di smartphone dapat diunduh pengguna sesuai dengan kebutuhannya. Seperti Tinder sebuah aplikasi pencarian jodoh yang telah banyak diunduh oleh penggunanya dengan tujuan untuk mencari teman kencan. Tentu Tinder bukan satusatunya aplikasi pencarian jodoh, sebut saja beberapa aplikasi pencarian jodoh lain seperti Beetalk, Ok Cupid, Downdating, wafo, badoo dan masih banyak lagi. Semua aplikasi tersebut ramai mendapat perhatian dari penggunanya. Aplikasi Badoo saat ini digunakan oleh sekitar 298 juta pemakai diseluruh dunia. Tinder menduduki peringkat kedua dengan jumlah pengguna aktif berjumlah 80 juta secara global. Sedang di Indonesia hingga saat ini, sudah ada 10 juta pengguna aktif (Amalia, dalam Http//:MetroTV.News.com diunduh 25 oktober 2016)

Aplikasi Tinder yang dirancang Sean Rad pada Oktober 2012 dapat membantu mempertemukan seseorang dengan pasangan yang diidamkan. (Amalia, dalam Http//:MetroTV.News.com diunduh 25 oktober 2016). Berbagai cerita perjodohan banyak terjadi pada situs pencarian jodoh tersebut, sebut saja salah satu perjodohan unik yang bermula dari aplikasi pencarian jodoh tinder yang dialami artis dan presenter Rey Utami yang menikah dengan pengusaha muda kaya raya Pablo Putera Benua tepat 7 hari setelah mereka berkenalan melalui Tinder. Kisah cinta mereka menjadi viral di media sosial sebab bukan saja terjadi secara instans, namun sebelum menikah yaitu tepatnya 2 hari setelah berkenalan Rey Utami diberi hadiah mobil HRV seharga 300 jutaan oleh Pablo, dan 4 hari setelah berkenalan Rey Utami kembali diberi hadiah jam tangan mewah merk Rolex seharga milyaran rupiah dan tepat pada hari ke lima Rey Utami dilamar, dan 2 hari kemudian mereka menikah. Jadi hanya memerlukan waktu satu minggu keduanya untuk memutuskan menikah setelah berkenalan melalui situs perjodohan Tinder. Selain kisah Rey Utami dan Pablo, kisah-kisah lain yang berawal dari aplikasi perjodohan Tinder tentu bak drama dan tak kalah serunya.

Berbagai penelitian mengenai situs pencarian jodoh Tinder juga sudah banyak dilakukan, salah satunya adalah penelitian yang dilakukan oleh Tessa Novala Putri (2015) menyimpulkan bahwa pria pengguna aplikasi Tinder menggunakan 
Merry Fridha, Meria Octavianti, Konstruksi Makna Kencan Di Situs Pencarian Jodoh Tinder (Studi Fenomenologi Pada Pria Pengguna Tinder Di Jakarta)

aplikasi ini didasari atas dasar meniru orang-orang di lingkungan sosialnya, mengisi kegiatan di waktu kosong, menunjukkan eksistensi didepan pengguna lain, keinginan untuk mempertahankan identitas dirinya, mencari perhatian lawan jenis untuk memperoleh suatu hubungan, mencari teman mengobrol untuk mereduksi tegangan, serta keinginan memperoleh penghargaan oleh lingkungan sekitarnya.

\section{Computer Mediated Communication (CMC)}

\section{Computer}

Mediated

Communication (CMC) menjadi dasar yang digunakan dalam penelitian ini. CMC sendiri didefinisikan sebagai suatu proses komunikasi yang dilakukan melalui komputer, yang melibatkan manusia yang terjadi pada konteks tertentu, dimana didalamnya melibatkan proses pembentukan media untuk berbagai tujuan. Hal ini sesuai dengan definisi computermediated communicationyang disampaikan oleh (Thurlow et al 2007:16) yaitu proses komunikasi antar manusia melalui komputer, melibatkan orang, terletak dalam konteks tertentu, terlibat dalam proses pembentukan media untuk berbagai tujuan. Dalam prakteknya, CMC biasanya dihubungkan secara lebih spesifik dengan komunikasi manusia maupun menggunakan komponen internet dan website.

Dalam buku Computer Mediated Communication : Social Interaction and The Internet, mendefinisikan CMC sebagai proses komunikasi manusia yang menggunakan komputer melibatkan orang, disituasikan dalam berbagai konteks, serta melibatkan proses-proses untuk membentuk media dengan tujuan yang beraneka ragam. Selain itu, komunikasi dengan media komputer (CMC) dapat didefinisikan juga sebagai transaksi komunikasi yang terjadi lewat dua buah atau lebih komputer yang berhubungan seperti chatting, instant messaging, jejaring sosial, dan email (December, 1997:35)

Berdasarkan hal tersebut lah maka tepat sekali bila penelitian ini menggunakan teori CMC sebagai dasar analisis dari fenomena mengkonstruksi makna kencan disebuah situs aplikasi pencarian jodoh. Seperti diketahui bersama bahwa saat ini sudah cukup banyak jenis media komunikasi dengan melalui media komputer. Media maupun fasilitas layanan yang terhubung dengan internet dapat digunakan secara mudah dan cuma-cuma, hal tersebutlah yang menjadi salah satu faktor yang menyebabkan banyaknya pengguna media baru ini. Berbagai fasilitas maupun layanan yang ada seperti 
Merry Fridha, Meria Octavianti, Konstruksi Makna Kencan Di Situs Pencarian Jodoh Tinder (Studi Fenomenologi Pada Pria Pengguna Tinder Di Jakarta)

email, chatting (Yahoo Messenger, MiRC), forum-forum di website (Kaskus, Tumblr, Flickr), jejaring sosial (facebook, twitter, Myspace) dan lain-lain dapat menciptakan hubungan-hubungan baru oleh penggunanya .

Computer

Communication (CMC) menjadi salah satu acuan utama literatur mengenai penggunaan teknologi di era digital seperti sekarang ini. Manusia sekarang memang sudah terbiasa hidup di kelilingi oleh berbagai teknologi yang beraneka ragam. Teknologi menjadi salah pendamping hidup yang harus dimiliki di kehidupan sehari-hari. Terlebih lagi teknologi mempunnyai sifat dinamis dan berkembang seiring berjalannya waktu dan hal tersebut ikuti oleh perkembangan teori CMC.

\section{Teori Penetrasi Sosial}

Teori Penetrasi Sosial dipopulerkan oleh Irwin Altman \& Dalmas Taylor. Teori Penetrasi Sosial berasumsi bahwa hubungan akan mengalami kemajuan dari tidak intim menjadi intim dan secara umum, perkembangan hubungan bergerak sistematis dan dapat diprediksi (West\&Turner: 2012:197). Dari asumsi akan teori tersebut maka dapat dilihat bahwa proses terjadinya pembangunan hubungan interpersonal berjalan secara bertahap dan berkembang serta bergerak mulai dari tingkatan yang paling dangkal menuju ke tingkatan yang terdalam, atau ke tingkatan yang lebih bersifat pribadi. Dengan penjelasan ini, maka teori penetrasi sosial dapat diartikan juga sebagai sebuah model yang menunjukkan perkembangan hubungan, yaitu proses di mana orang saling mengenal satu sama lain melalui tahap pengungkapan informasi.

Teori penetrasi sosial menggambarkan suatu pola pengembangan hubungan yang di ibaratkan sebagai sebuah proses yang mereka identifikasi sebagai penetrasi sosial. Penetrasi Sosial (Sosial Penetration) merujuk pada sebuah proses ikatan hubungan dimana individuindividu bergerak dari komunikasi superfisisal menuju ke komunikasi yang lebih intim. Menurut Altman dan Taylor, keintiman disini lebih dari keintiman secara fisik; dimensi lain dari keintiman termasuk intelektual dan emosional, dan hingga pada batasan dimana pasangan melakukan aktifitas bersama (West\&Turner, 2012: 198).

Proses Penetrasi sosial mencakup didalamnya perilaku verbal (kata-kata yang digunakan), perilaku nonverbal (postur tubuh, senyum dsb), dan perilaku yang berorientasi pada lingkungan (ruang antara komunikator, objek fisik yang didalam lingkungan dsb). Maka dari 
Merry Fridha, Meria Octavianti, Konstruksi Makna Kencan Di Situs Pencarian Jodoh Tinder (Studi Fenomenologi Pada Pria Pengguna Tinder Di Jakarta)

cakupan diatas dapat dikenal 4 tahapan dalam proses pengembangan hubungan interpersonal.

Tahap Pertama (Lapisan Pertama atau Terluar Kulit Bawang) : lapisan kulit terluar dari kepribadian manusia adalah apa-apa yang terbuka bagi publik, apa yang biasa kita perlihatkan kepada orang lain secara umum, tidak ditutup-tutupi. Tahap Kedua (Lapisan Kulit Bawang Kedua) : tahap kedua (lapisan kulit bawang kedua) ini disebut juga dengan tahap pertukaran afektif eksploratif. Pada tahap ini, di antara dua orang yang berkomunikasi, mulai bergerak mengeksplorasi ke soal informasi yang berupaya menjajagi apa kesenangan masing-masing, misalnya kesenangan dari segi makanan, musik, lagu, hobi, dan lain sejenisnya. Tahap Ketiga (Lapisan Kulit Bawang Ketiga), yaitu tahapan pertukaran afektif yang berupa peningkatan informasi yang lebih bersifat pribadi, dimana masing-masing sudah mulai membuka diri dengan informasi diri yang sifatnya lebih pribadi, misalnya seperti kesediaan menceritakan tentang problem pribadi. Dengan kata lain, pada tahap ini sudah mulai berani "curhat". Tahap Keempat (Lapisan Kulit Bawang Keempat), yaitu tahapan akhir atau lapisan inti yang disebut juga dengan tahap pertukaran yang stabil. Tahap akhir in sifatnya sudah sangat intim dan memungkinkan pasangan tersebut untuk memprediksikan tindakan-tindakan dan respon mereka masing-masing dengan baik. Informasi yang dibicarakan sudah sangat dalam dan menjadi inti dari pribadi masing-masing pasangan, misalnya soal nilai, konsep diri, atau perasaan emosi terdalam (West\&Turner, 2012: 200).

\section{METODE PENELITIAN}

Peneliti dalam melakukan penelitian ini menggunakan metode penelitian kualitatif. Penelitian kualitatif adalah metode yang digunakan untuk meneliti pada kondisi obyek yang alamiah (sebagai lawannya adalah eksperimen) dimana peneliti adalah sebagai instrumen kunci, teknik pengumpulan data dilakukan secara triangulasi (gabungan), analisis data bersifat induktif, dan hasil penelitian kualitatif lebih menekankan makna daripada generalisasi (Sugiyono 2010: 12).

Penelitian ini juga menggunakan pendekatan fenomenologi. Dalam penelitian fenomenologi melibatkan pengujian yang teliti dan seksama pada kesadaran pengalaman manusia. Konsep utama dalam fenomenologi adalah makna. Makna merupakan isi penting yang muncul dari pengalaman kesadaran manusia. Untuk mengidentifikasi kualitas yang essensial dari pengalaman kesadaran dilakukan dengan mendalam dan teliti. 
Merry Fridha, Meria Octavianti, Konstruksi Makna Kencan Di Situs Pencarian Jodoh Tinder (Studi Fenomenologi Pada Pria Pengguna Tinder Di Jakarta)

Prinsip-prinsip penelitian fenomenologis ini pertama kali diperkenalkan oleh Edmund Husserl. Husserl mengenalkan cara mengekspos makna dengan mengeksplisitkan struktur pengalaman yang masih implisit (Smith, ed. 2009: 12).
Analisis data dalam penelitian ini dilakukan dengan mengggunakan interactive model seperti yang digambarkan dalam bagan di bawah ini :

Bagan 1

Komponen Analisis data Model Interaktif (Interactive Model)

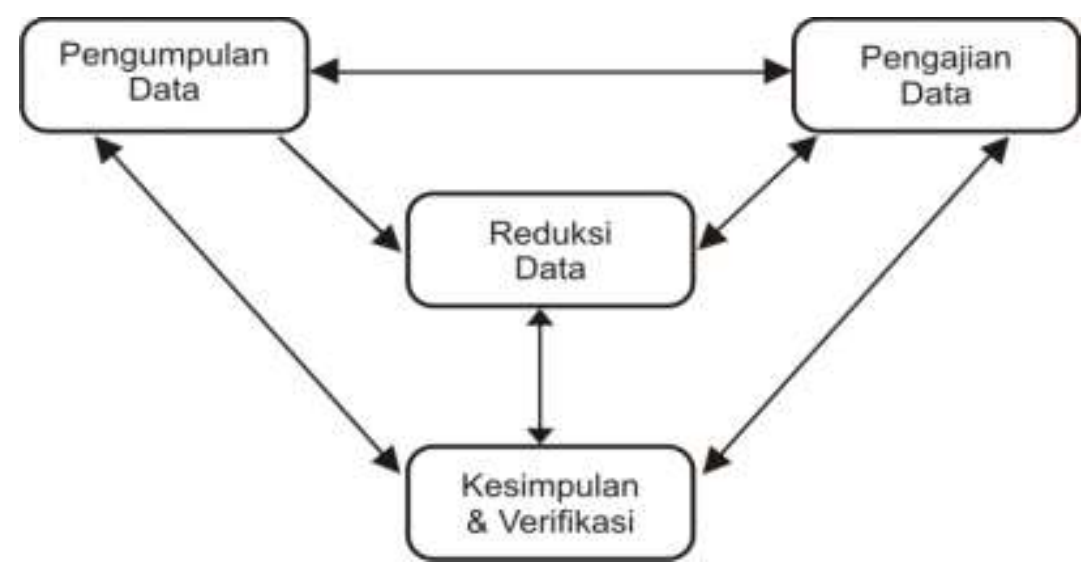

Sumber: Miles \& Huberman dalam Agus Salim 2006: 22

Dari bagan di atas tergambar bahwa analisis data dilakukan melalui tiga tahap yaitu (1) proses pemilihan, pemusatan perhatian pada penyederhanaan, abstraksi, dan transformasi data kasar yang di peroleh di lapangan atau yang biasa dikenal dengan reduksi data (data reduction), (2) penyajian data (data display), yaitu mendeskripsikan kumpulan informasi yang telah tersusun, untuk selanjutnya dilakukan
(3) penarikan kesimpulan dan verifikasi (conclusion drawing and verification). Hal tersebut dilakukan sejak pengumpulan data dimulai. Peneliti mencari makna dari setiap gejala yang diperoleh di lapangan, mencatat keteraturan atau pola penjelasan dan konfigurasi yang mungkin ada, alur kausalitas, dan proposisi. Selama penelitian masih berlangsung, setiap kesimpulan yang ditetapkan akan terusmenerus diverifikasi hingga benar-benar 
Merry Fridha, Meria Octavianti, Konstruksi Makna Kencan Di Situs Pencarian Jodoh Tinder (Studi Fenomenologi Pada Pria Pengguna Tinder Di Jakarta)

diperoleh kesimpulan yang valid dan kokoh.

\section{Pembahasan}

Dalam penelitian ini, peneliti melakukan pengumpulan data wawancara secara online dan offline. Pengumpulan data secara online yaitu dengan mewawancarai informan melalui aplikasi jejaring sosial tinder dengan melakukan chatting kepada informan dan observasi online dimana peneliti menggunggah lalu menggunakan aplikasi Tinder untuk melihat aktivitas di dalam aplikasi tersebut, dan untuk melengkapi data mengenai aktivitas pengguna Tinder dalam penelitian ini, peneliti juga melakukan wawancara mendalam terhadap subyek penelitian (penggalian secara offline).

Informan dalam penelitian ini berjumlah tiga orang, yaitu Patrick seorang ekspatriat disebuah perusahaan multinasional berusia 36 tahun yang berkantor di Kuningan Jakarta Selatan, Brian 33 tahun karyawan perusahaan asuransi berkantor di Kelapa Gading Jakarta Utara, dan Al Marsah 35 tahun karyawan perusahaan Multinasional yang berkantor di Jenderal Sudirman Jakarta Pusat. Selain ketiga orang narasumber utama peneliti juga mewawancarai satu narasumber pendukung yaitu Amanda seorang gadis berusia 28 tahun yang bekerja sebagai manajer café di sebuah pusat perbelanjaan di kawasan Jakarta Pusat.

Tabel 2

Data Informan

\begin{tabular}{|l|l|l|l|l|}
\hline No & Nama Informan & Status & Usia & Pekerjaan \\
\hline 1. & Patrick & Belum Menikah & 36 Tahun & Direktur PMA \\
\hline 2. & Brian & Telah Menikah & 33 Tahun & $\begin{array}{l}\text { Manager Area } \\
\text { Perusahaan Asuransi }\end{array}$ \\
\hline 3. & Al Marsah & Telah Menikah & 35 Tahun & Karyawan Swasta \\
\hline 4 & Amanda & Belum Menikah & Manager & Manager cafe \\
\hline
\end{tabular}

Data: Diolah Peneliti 
Merry Fridha, Meria Octavianti, Konstruksi Makna Kencan Di Situs Pencarian Jodoh Tinder (Studi Fenomenologi Pada Pria Pengguna Tinder Di Jakarta)

Aplikasi Tinder digunakan untuk

\section{Mengisi Waktu Luang}

Melalui hasil wawancara dengan narasumber diketahui bahwa ketiga nara sumber inti dan satu nara sumber tambahan mengatakan bahwa awalnya mereka hanya mencoba-coba dalam menggunakan aplikasi tersebut. Hal ini seperti disampaikan Patrick: "Awalnya saya hanya mencoba-coba saja, bila saya jenuh dengan pekerjaan. Dan saya ingin banyak mengenal perempuan Indonesia”

Sedangkan Amanda, narasumber tambahan mengatakan bahwa ia mengetahui aplikasi Tinder melalui temannya. Amanda yang memang bule hunter atau pemburu laki-laki eksptariat yang berada di Jakarta sering berkencan melalui aplikasi tinder. Ia amanda mengatakan bahwa "Di dunia nyata lebih susah bertemu orang baru karena sibuk kerja, tapi di Tinder lebih mudah mencari cowok bule. Sudah pernah bertemu tiga pria, besok baru mau yang keempat. Ada yang dari Singapura, Tunisia, Belgia, dan Rusia. Ya namanya juga usaha"

Brian dan Al Marsah, ditempat yang berbeda juga mengatakan iseng merupakan motif utamanya menggunakan aplikasi Tinder. Brian dan Al Marsah merupakan laki-laki beristri, yang ingin mencari teman perempuan untuk diajak berkencan. Hal ini seperti dikatakan Brian
"Aku udah nikah sih, iseng aja pake Tinder. Aku tau Tinder ini dari tementemen kantor, kayaknya seru. Jadi ikutan pake" Dari penrnyataan narasumber dapat diketahui bahwa motif narasumber menggunakan Tinder hanya iseng dan coba-coba saja.

\section{Aplikasi Tinder Digunakan sebagai Media Hiburan}

Al Marsah salah seorang narasumber mengatakan bahwa "Walau udah nikah, dan hubunganku dengan istri baik-baik saja tapi aku iseng pake aplikasi ini. Ya ibaratnya kalau tiap hari makan pake sayur asem bosen dong, aku pingin coba makan sayur sop,lodeh dan yang lainnya hehehe...." . Lain lagi dengan Brian sebagai manager area perusahaan asuransi yang sering mengadakan perjalanan dinas keluar kota, Brian kerap berkencan dengan beberapa perempuan yang dikenalnya melalui aplikasi Tinder. Brian mengatakan "Kalau lagi di luar kota, aku sering jenuh sendiri. Makanya aku pake Tinder untuk mencari teman kencan".

Melalui hasil wawancara diatas terlihat bahwa aplikasi Tinder digunakan tidak hanya oleh laki-laki lajang atau yang belum beristri, namun laki-laki beristri juga menggunakan aplikasi tinder untuk mencari hiburan kala sedang jenuh dan juga mencari teman kencan. Makna kencan 
Merry Fridha, Meria Octavianti, Konstruksi Makna Kencan Di Situs Pencarian Jodoh Tinder (Studi Fenomenologi Pada Pria Pengguna Tinder Di Jakarta)

yang di dapat melalui wawancara dengan narasumber bahwa kencan hanya lah bagian dari kegiatan sampingan, hiburan dari kejenuhan akan pekerjaan maupun memupus kesepian kala dinas keluar kota.

\section{Pencarian Jodoh melalui Aplikasi}

Tinder Bak Membeli Barang melalui Online Shop

Melalui hasil wawancara dengan narasumber diketahui bahwa kemudahan akan penggunaan aplikasi perjodohan Tinder membuat narasumber menggunakan aplikasi ini. Seperti dikatakan Brian: "Iya mudah banget tinggal download aja di hp. Trus mau cari cewek yang kayak gimana, ada semua di Tinder"

Salah seorang narasumber yaitu $\mathrm{Al}$ Marsah, mengatakan alasannya dalam menggunakan Tinder yaitu: "Aku tuh suka jenuh kalo keluar kota mbak, jadi pake aplikasi ini untuk cari temen. Jadi kan gak kesepian pas diluar kota”. Berbeda dengan Al Marsah, Patric yang seorang ekspatriat dari Australia mengatakan bahwa dengan Tinder membuat dia memiliki banyak teman terutama perempuan: "Terhubung dengan aplikasi ini membuat aku memiliki banyak pilihan bila ingin mengencani perempuan. Aku tinggal memilih perempuan yang sesuai dengan tipe ku. $\mathrm{Aku}$ tinggal memberi tanda love untuk perempuan yang menarik hati ku, dan bila tidak sesuai aku tinggal memberi tanda silang. Mudahkan?"

\section{Makna Kencan pada Laki-laki}

\section{Pengguna Aplikasi Tinder}

Dalam Kamus Besar Bahasa Indonesia (KBBI) yang diunduh secara online kencan di artikan sebagai janji untuk saling bertemu di suatu tempat pada waktu yang telah ditentukan bersama (antara teman, muda-mudi, atau kekasih) (KBBI versi online diunduh 25 Oktober 2016). Dalam kepercayaan yang dipercaya oleh masyarakat Indonesia, kencan akan dilakukan oleh sepasang kekasih atau sepasang muda mudi pada masa penjajakan menjadi kekasih. Hal ini seperti terdapat pada teori penetrasi sosial yang menganalogikan sebuah hubungan dengan kulit bawang.

Analogi kulit bawang, yang dicetuskan oleh Altman dan Taylor mengibaratkan manusia seperti bawang merah. Maksudnya adalah pada hakikatnya manusia memiliki beberapa layer atau lapisan kepribadian. Jika kita mengupas kulit terluar bawang, maka kita akan menemukan lapisan kulit yang lainnya. Begitu pula kepribadian manusia.

Analogi kulit bawang melihatproses keterbukaan seseorang 
Merry Fridha, Meria Octavianti, Konstruksi Makna Kencan Di Situs Pencarian Jodoh Tinder (Studi Fenomenologi Pada Pria Pengguna Tinder Di Jakarta)

terhadap sekitarnya. Lapisan paling luar dari kulit bawang, dianalogikan sebagai lapisan manusia yang terbuka bagi publik. Lapisan paling luar inilah yang menjadi penilaian pertama publik atas pribadi seseorang. Dan jika kita bisa mengupas lapisan itu, maka kita bisa melihat lapisan yang tidak terbuka bagi semua orang. Lapisan ini memiliki lebih sedikit jumlah orang yang bisa melihatnya. Begitu pun lapisan yang lebih dalam lagi, berlaku hal yang sama.

Analogi kulit bawang juga memperlihatkan sebuah hubungan akan bergerak dari hubungan yang bersifat artifisial atau hanya kenal dipermukaan saja bergerak menjadi sebuah hubungan yang menuju kehubungan yang lebih intim. Namun dalam fenomena laki-laki pengguna tinder dalam penelitian ini terlihat bahwa tahapan kencan, dipotong sehingga antara narasumber dan pasangan kencannya tidak melalui tahapan perkenalan, pendekatan, penjajajakan, intim lalu kencan. Namun langsung dari perkenalan langsung kencan.Hal ini seperti disampaikan Al Marsah, dalam sebuah wawancara: “ Di awal chatting aku langsung tanya ke cewek itu, mau cari teman biasa atau teman kencan. Trus aku juga jujur kalau aku cari teman kencan dan aku ngajakin hooking up. Aku sih gak pernah maksa ya...mau ya hayo..gak mau ya cari yang mau hahaha".

Melalui penelusuran di internet peneliti mendapatkan arti dari istilah hooking up yaitu sebuah kondisi di mana dua orang (bisa kenal baik atau hanya sekedar kenal) kencan dengan tujuan cuma main-main. Dalam kencan tersebut keduanya melakukan aktifitas seperti ciuman, petting, atau bahkan sampai pada hubungan badan. Yang menjadi sorotan adalah bahwa hooking up lebih mendahulukan kepuasan fisik daripada kebutuhan emosional.

Dari wawancara diatas terlihat bahwa narasumber memaknai kencan sebagai hal yang ringan, bahkan tanpa melibatkan sisi emosional. Hal ini seperti disampaikan Patrick "So far aku sudah 5 kali kencan melalui tinder. Tiga diantaranya berakhir ditempat tidur. Ada yang sampai satu tahun aku pacaran, tapi pisah karena beda agama. Menurut aku syarat kencan melalui tinder, tidakboleh baper ya..."

Dari fenomena tersebut dapat dilihat bahwa pergeseran makna intim telah mengalami pergeseran seperti disampaikan dalam teori penetrasi sosial. Keakraban atau kkeintiman bagi laki-laki pengguna tinder bisa berlangsung sambil berjalan. Hal ini seperti disampaikan Brian: "Ya menurut aku sih akrab itu bisa 
Merry Fridha, Meria Octavianti, Konstruksi Makna Kencan Di Situs Pencarian Jodoh Tinder (Studi Fenomenologi Pada Pria Pengguna Tinder Di Jakarta)

sambil jalan, gak cocok ya gak usah lanjut, make a simple hahaha"

Sedang Al Marsah mengatakan bahwa di jaman teknologi informasi yang canggih saat ini akrab atau banyak tahu tentang orang lain caranya sangat mudah: “ Gampang mbak ajak chatting aja, trus add semua sosmednya. Pantengin deh postingannya, statusnya, gambarnya, atau locationnya jadi kita tau doi lagi aktivitas apa, dimana dan ama siapa"

Dari wawancara diatas dapat dilihat bahwa konstruksi makna kencan oleh lakilaki pengguna Tinder di Jakarta bahwa kencan merupakan sustu hubungan yang dilakukan suka sama suka, tanpa paksaan, dan cenderung mengarah kehubungan seksual tanpa didasari oleh paksaan. atrifisial menuju hubungan yang semakin intim. Namun dewasa ini hubungan intim atau kencan dapat dilakukan oleh dua orang muda-mudi tanpa melalui proses yang panjang dan ikatan emosional yang mendasari.

Memilih lawan kencan di aplikasi Tinder dimaknai seperti mencari barang di online shop, apabila sesuai dengan harapan dan keinginan maka proses perkenalan akan berlanjut pada tahap kencan, sedang bila tidak menemukan kecocokan maka laki-laki pengguna aplikasi Tinder di Jakarta akan mencari perempuan pengguna Tinder lain yang mereka anggap cocok dan sesuai dengan kriteria mereka. Mencari teman kencan dilakukan saat sedang ada waktu luang atau berada diluar kota atau ketika jenuh sehingga kencan dimaknai sebagai sebuah hiburan.

\section{Daftar Pustaka}

Ardianto, Elvinaro. 2007. Komunikasi Massa Suatu Pengantar. Bandung : Simbosa Rekatama Media

Daryanto, 2007. Pengetahuan Dasar Ilmu Komputer. Bandung: Yrama Widya

December, John. 1997. Computer Mediated Communication: Social Interaction and the internet. London: Sage Publication: Florida

Finkel Eli J., Eastwick, Paul W., Karney, Benjamin R., Reis Harry T., Sprecher, Susan., 2012, Online Dating: A Critical Analysis From 
the Perspective of Psychological Science, diakses pada https://www3.nd.edu/ ghaeffel/Oni neDating_Aron.pdf. pada tanggal 29 Desember 2016

Sugiyono. 2010. Metode Penelitian Kuantitatif, Kualitatif, $R \& D$. Bandung: Alfabeta

Smith, Jhonathan A. (ed). 2009. Psikologi Kualitatif: Panduan Praktis Metode Riset, Terjemahan dari Qualitatif Psichology A Practical Guide To Research Method. Yogyakarta: Pustaka Pelajar.

Thurlow dkk. 2004. Computer Mediated Communication Social Interaction and The Internet. London: Sage Publication: Florida

Parks, M. R. and Floyd, K.1996. Making Friends in Cyberspace. Journal of Communication, VOL 46

Putri, Novala, Tessa, 2015, Motif Pria Pengguna Tinder Sebagai Jejaring Sosial Pencarian Jodoh: Studi Virtual Etnografi Mengenai Motif Pria Pengguna Tinder. Karya Skripsi yang tidak dipublikasikan Program Studi Ilmu Komunikasi, Fakultas Komunikasi \& Bisnis, Universitas Telkom Bandung

Salim, Agus. 2006. Teori dan Paradigma Penelitian Sosial. Yogyakarta: Tiara Wacana

West, Ricard \& Lynn H. Turner. 2012. Pengantar Teori Komunikasi, Analisis dan Aplikasi. Terjemahan dari Introducing Communication Theory: Analysis and Application. Jakarta: Salemba Humanika

Sumber lain:

Amalia, Pengguna Internet dan Smartphone di Indonesia menuju 100\% diunduh 25 oktober 2016 Http//:MetroTV.News.com

Kamus Besar Bahasa Iindonesia versi online diunduh 25 Oktober 2016 
Merry Fridha, Meria Octavianti, Konstruksi Makna Kencan Di Situs Pencarian Jodoh Tinder (Studi Fenomenologi Pada Pria Pengguna Tinder Di Jakarta) 